\title{
HUKUM YANG HIDUP DALAM MASYARAKAT UNTUK MENGKUALIFIKASIKAN LESBIAN, GAY, BISEKS, DAN TRANSGENDER SEBAGAI TINDAK PIDANA
}

\author{
Bahrul Ulum, S.H, M.H \\ Dosen PAI STAI Darul Hikmah Bangkalan
}

\begin{abstract}
Abstrak
Melalui prespektif hukum Islam masyarakat, penulis berusaha menganalisis dan mendefinisikan hakikat perilaku tersebut, apakah perilaku LGBT dapat dikualifikasikan sebagai tindak pidana atau tidak. Dengan memakai pendekatan masalah konseptual dan komparatif, penulis mencoba menemukan teori, konsep dan doktrin hukum yang relevan untuk membangun argumentasi dan menemukan jawaban yang valid dan konkrit. Dari hasil penelitian dapat disimpulkan, perilaku LGBT dapat dikualifikasikan sebagai tindak pidana dengan jenis crimina extra ordinaria/mala in se, suatu perbuatan yang dianggap jahat dan merugikan oleh masyarakat meskipun tidak diatur dalam undang-undang, hal ini disebakan karena perilaku tersebut bertentangan dengan hukum yang hidup dalam masyarakat, yang sarat akan nilai-nilai adiluhung bangsa Indonesia yang religius, adil dan beradab. Sehingga meskipun perilaku tersebut tidak diatur oleh Undang-undang, dapat/memungkinkan untuk dipidana, berdasarkan doktrin ajaran sifat melawan hukum materiil dengan fungsinya yang positif
\end{abstract}

Kata Kunci: LGBT. Hukum Yang Hidup Dalam Masyarakat. Tindak Pidana.

\begin{abstract}
From the perspective of Islamic law, the writer seeks to analyze and define the nature of such behavior, whether LGBT conduct can be categorized as a crime or not. By using conceptual and comparative approach to the problem, the writer tries to find relevant theories, concepts, and doctrine to build up arguments and find valid and concrete answers. From the results of this study, it can be concluded that LGBT conduct can be categorized as a crime with type of crimina extra ordinaria / mala in se, an act that is considered evil and detrimental by public voice despite being not regulated by law. it is because such behavior contradicts with living law in society that is viscous with values of Indonesian nationalism which are religious, just and civilized. Thus, although it is not officially regulated within decree, based on the doctrine that it is against material sources of law with its positive function, such conduct can/may be judged as crime.
\end{abstract}

Keywords: LGBT. Living Law. Crime 


\section{Pendahuluan}

Persoalan LGBT di Indonesia telah menciptakan dinamika sosial yang cukup pelik dan dikhawatirkan dapat mengganggu stabilitas sosial masyarakat. Kalangan yang menentang tindakan LGBT memiliki banyak alasan untuk menegaskan bahwa tidak seharusnya LGBT dilegalkan di Indonesia. Salah satunya adalah adanya nilainilai luhur Pancasila. Indonesia memiliki pancasila sebagai ideologi bangsa. Sebagai ideologi pancasila berhak untuk memberikan pandangan hidup dan batasan - batasan kehidupan bagi seluruh bangsa Indonesia

Perubahan sosial membawa permasalahan hukum tidak dapat dipungkiri pada era yang semakin maju ini. Kondisi demikian membuat instrumen hukum pidana terlihat ketinggalan dan kurang memadai bagi perubahan sosial itu. Hal demikian menuntut hukum pidana untuk mengikuti perubahan itu dan mengatasi permasalahan hukum yang mengganggu keseimbangan hukum di masayarakat. Salah satu contohnya adalah masalah mengenai LGBT. Di dalam KUHP LGBT yang disebut dengan Perbuatan cabul sesama jenis atau homoseksual merupakan bagian dari materi terkait norma kesusilaan.

Masalah hukum mengenai perbuatan cabul yang dilakukan oleh pasangan sesama jenis, dapat kita cermati dari rumusan Pasal 292 KUHP. ${ }^{1}$ Konsep Pasal ini hanya mengatur ancaman pidana bagi orang dewasa baik laki-laki maupun perempuan yang melakukan perbuatan cabul terhadap orang yang belum dewasa dan orang yang belum dewasa tersebut memiliki jenis kelamin yang sama dengannnya. Sementara kenyataan dimasyarakat menunjukkan perkembangan komunitas homoseksual, baik gay maupun lesbian berkembang di Indonesia. ${ }^{2}$ Berdasarkan konsep pasal tersebut, dapat dipahami bahwa, hukum pidana tidak mengatur tentang bagaimana ancaman pidana atau konsekuensi hukum perbuatan cabul yang dilakukan oleh orang dewasa yang memiliki jenis kelamin yang sama. Hal demikian membuat kekosongan norma (vacuum of norm).

\footnotetext{
${ }^{1}$ Ibid

${ }^{2}$ www.gayanusantara.or.id
} 
Ketiadaan aturan hukum tertulis, yang secara tegas melarang praktek LGBT di Indonesia merupakan peluang, terhadap semakin maraknya aksi yang dilakukan oleh Kaum LGBT, untuk menuntut persamaan hak dan perlindungan hukum terhadap komunitas dan perilaku mereka yang menyimpang. Bahkan perilaku tersebut sudah tidak lagi dilakukan secara tertutup seperti dulu, tetapi dengan terang-terangan ada beberapa anggota mereka yang melakukan perkawinan sejenis secara terbuka di indonesia.

\section{Metode Penelitian}

Dalam penelitian ini, penulis memilih penelitian hukum dengan jenis penelitian theoritical reseach, dengan menggunakan 2 (dua) pendekatan masalah yaitu konseptual dan komparatif . Pendekatan konseptual adalah pendekatan yang beranjak dari pandangan-pandangan dan doktrindoktrin yang berkembang di dalam ilmu hukum. Karena belum adanya aturan hukum yang mengatur persoalan LGBT secara jelas, maka diharapkan dengan mempelajari pandangan dan doktrin-doktrin di dalam ilmu hukum, penulis akan menemukan pengertian-pengertian hukum,konsepkonsep hukum, dan asas-asas hukum yang relevan untuk menjadi sandaran dalam membangun argumentasi hukum dalam memecahkan isu yang dihadapi ${ }^{3}$.

Sedangkan pendekatan komparatif dipilih dalam rangka membandingkan antara aturan hukum di Indonesia dengan beberapa Negara baik yang sudah melegalkan LGBT maupun yang tidak, dengan harapan penulis dapat menemukan pemahaman, tentang konsistensi dari nilai filosofi yang melahirkan aturan hukum dengan ketentuan hukum yang ada diberbagai Negara tersebut ${ }^{16}$.

\section{Instrumen/Teknik Pengumpulan Bahan Hukum}

Instrumen yang digunakan dalam penelitian ini ada 2 (dua) yaitu, Bahan hukum sekunder dan bahan hukum tersier. Bahan Hukum sekunder adalah bahan hukum berupa buku-buku hukum termasuk skripsi, tesis, disertasi hukum dan jurnal-

\footnotetext{
${ }^{3}$ Peter Mahmud Marzuki, Penelitian Hukum Edisi Revisi, Prenada Media Group, 2005, h.135136. ${ }^{16}$ Ibid
} 
jurnal hukum serta Rancangan KUHP. Sumber bahan hukum sekunder inilah yang akan menjadi acuan utama dalam membangun argumentasi pemecahan masalah.

Sedangkan bahan hukum tersier berupa, kamus-kamus hukum, ensiklopedia dan komentar-komentar atas putusan pengadilan yang memiliki relevansi dengan isu hukum yang diteliti, dan akan menjadi bahan penunjang bagi bahan hukum sekunder.

Sebagai pelengkap digunakan juga bahan non hukum yaitu bahanbahan yang memiliki keterkaitan dengan obyek penelitian seperti literature yang memuat tentang pengertian dan sejarah LGBT, pendapat dokter tentang LGBT dan pengetahuan lain yang dapat membantu penulis dalam menganalisis dan mengidentifikasi apa sebenarnya LGBT dan seperti apa keterkaitannya dengan Hukum ${ }^{4}$.

\section{LGBT Dalam Prespektif Hukum Yang Hidup Dalam Masyarakat}

Sebagaimana hukum adat banyak dipengaruhi oleh norma-norma agama sebagai bagian dari akulturasi budaya, maka di dalam konkretisasi norma-norma hukum adat tidak jauh berbeda dengan norma-norma agama, seperti akuIturasi Islam terhadap hukum adat di Aceh, Hindu di Bali, Kristen di Ambon dan Maluku dan sebagainya,

Islam menetapkan tindakan homoseksual sebagai perilaku terlarang. Hal tersebut sudah ditegaskan oleh para ulama terdahulu. Dalam hal ini mereka sama sekali tidak berselisih. Perbedaan pendapat terjadi berkenaan dengan hukuman bagi para pelaku praktik homoseksual.

Para ulama jarang menyinggung ketertarikan seks sesama jenis, hanya pada praktik homoseksual yang dinyatakan terlarang. Walaupun tidak membicarakan orientasi seksual secara khusus,

Islam menganjurkan umatnya untuk menerapkan adab dan perilaku islami sejak kecil. Misalnya, laki-laki tidak boleh meniru wanita dan sebaliknya. Contoh lain, memisahkan selimut saat tidur meskipun itu sesama laki-laki dan bersaudara.

\footnotetext{
${ }^{4}$ Ibid, h. 205
} 
Berikut ini larangan liwath atau tindakan homoseksual menurut Al-Qur'an, hadis, dan pemahaman para ulama salaf (terdahulu) Dalam Al-Qur'an, larangan praktik homoseksual jelas tertera dalam kisah kaum Nabi Luth di negeri Sodom. Mereka melakukan perbuatan maksiat yang baru pertama kali dilakukan di muka bumi, yaitu hubungan seksual sesame Jenis.

Sedangkan hadis yang melarang praktik homoseksual, seperti

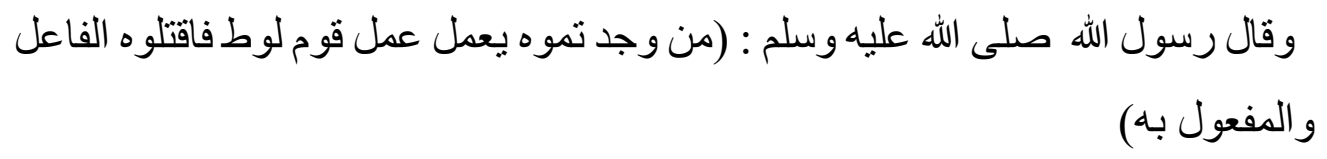

artinya "Barangsiapa yang kalian dapati melakukan perbuatan kaum Luth, maka bunuhlah kedua pelakunya". 5

$$
\text { قال رسول الله صلى الله عليه وسلم إن أخوف ما أخا ف على أمتي عمل قوم لوط }
$$

Berdasarkan Al-Qur'an dan hadis, para ulama terdahulu sepakat bahwa hukum perbuatan homoseksual adalah haram. Hal ini dapat diketahui dari beberapa pernyataan berikut ini

Ibnu Qudamah Maqdisi menyebutkan bahwa penetapan hukum haramnya Praktik homoseksual adalah ijma (kesepakatan) ulama berdasarkan nash-nash AlQur'an dan Al-Hadis. ${ }^{6}$

Imam Al berkata, Mawardi "Penetapan hukum haramnya praktik homoseksual menjadi ijma dan itu diperkuat oleh nash-nash Al-Qur'an dan AlHadis." ${ }^{7}$ Tentang keharaman tindakan homoseksual, para ulama sudah tidak berbeda pendapat lagi tentangnya. Yang masih menjadi perselisihan adalah hukuman bagi orang yang melakukan tindakan homoseksual setelah berlalunya kaum Luth.

Berikut ini beberapa kutipan ijma para ulama tentang hukuman bagi orang yang melakukan aktivitas homoseksual Imam Abu Hanifah (pendiri mazhab Hanafi) berpendapat bahwa praktik homoseksual tidak dikategorikan zina dengan beberapa

\footnotetext{
${ }^{5}$ HR. Tirmidzi, Al Majalis Al Wa'idiyah Fi Syarhi Al Ahadist Khoiril Bariyah Juz, 2, Annasyir

Dar Al Kutub Ilmiyah, Bairut libanon, h. 154

${ }^{6}$ Ibnu Qudamah, Al Mughni juz 10, Maktabah Alqohiroh, h. 60.

${ }^{7}$ Abu Hasan, Al Hawi Al Kabir juz 13, dar alkutub alamiah, Bairut Libanon, h. 222.
} 
alasan. Pertama, karena tidak adanya unsur (kriteria) kesamaan antara keduanya. Unsur menyia-nyiakan anak dan ketidakjelasan nasab (keturunan) tidak didapatkan dalam praktik homoseksual. Kedua, berbedanya jenis hukuman yang diberlakukan para sahabat. Berdasarkan kedua alasan ini Abu Hanifah berpendapat bahwa hukuman terhadap pelaku homoseksual adalah ta'zir (diserahkan kepada penguasa atau pemerintah). ${ }^{8}$

Menurut Muhammad Ibn Al Hasan As Syaibani dan Abu Yusuf (murid Abu Hanifah), praktik homoseksual dikategorikan zina karena adanya beberapa unsur kesamaan antara keduanya. Pertama, tersalurkannya syahwat pelaku. Kedua, tercapainya kenikmatan (karena penis dimasukkan ke lubang dubur Ketiga, tidak diperbolehkan dalam Islam. Keempat, menumpahkan (menyia-nyiakan) air mani.

Berdasarkan alasan-alasan tersebut, Abu bakar bin muhammad berpendapat bahwa hukuman terhadap pelaku homoseksual sama seperti hukuman yang dikenakan kepada pezina. Kalau pelakunya muhshan (sudah menikah), maka dihukum rajam (dilempari dengan batu sampai mati. Kalau gair muhshan (perjaka), maka dihukum cambuk dan diasingkan selama satu tahun. ${ }^{9}$

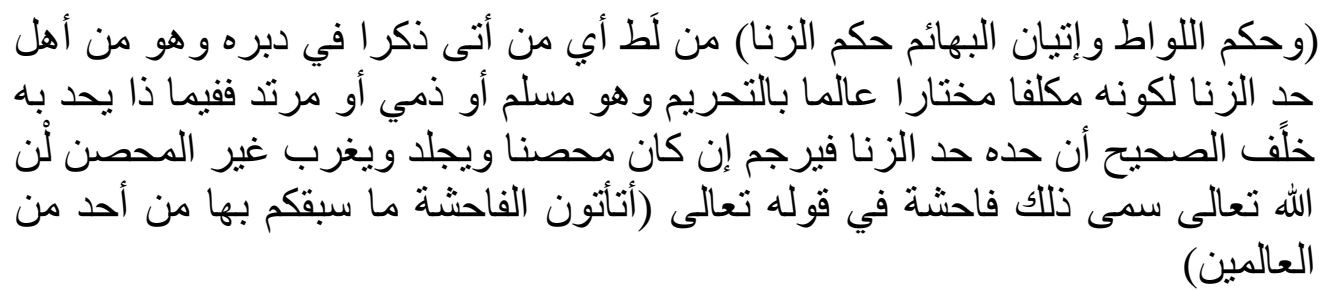

Menurut Abu bakar bin muhammad, praktik homoseksual dikategorikan zina dan hukuman yang setimpal untuk pelakunya adalah dirajam, baik pelakunya muhshan (sudah menikah) maupun gair mushan (perjaka). Ia sependapat dengan Ishaq bin Rahawaih dan As Sya'bi.

Menurut Imam Syafi'i, praktik homoseksual tidak dikategorikan zina, tetapi terdapat kesamaan, yaitu keduanya sama-sama merupakan hubungan seksual terlarang dalam Islam. Hukuman untuk pelakunya: kalau pelakunya muhshan (sudah

\footnotetext{
${ }^{8}$ Muhammad As-Syaukani, Fathul Qadir juz 5, Annasyir Darul Fikri, h. 349.

9 Taqiyud Diin Abi Bakar Bin Muhammad AlHusaini, Kifayatul akhyar juz 1, Dar Al- Khair Dimisyq, h. 476.
} 
menikah), maka dihukum rajam. Kalau gair muhshan (perjaka), maka dihukum cambuk 100 kali dan diasingkan selama satu tahun. Hal tersebut sama dengan pendapat Said bin Musayyib, Atha' bin Abi

Rabah, An Nakha'i, Al Hasan, dan Qatadah. Menurut Imam Hambali, praktik homoseksual dikategorikan zina. Mengenai jenis hukuman yang dikenakan kepada pelakunya, beliau mempunyai dua riwayat (pendapat). Pertama, dihukum sama seperti pezina. Kalau pelakunya muhshan (sudah menikah) maka dihukum rajam. Kalau pelakunya gair muhshan (perjaka), maka dihukum cambuk 100 kali dan diasingkan selama satu tahun. Kedua, dibunuh dengan dirajam, baik dia itu muhshan maupun ghairu muhshan. ${ }^{10}$

Dalam agama Katolik, aktivitas homoseksual adalah sesuatu yang bertentangan dengan hukum alam dan penuh dosa, sementara keinginan dan nafsu homoseksual adalah suatu kelainan (namun hal ini sendiri belum sepenuhnya dosa). Gereja Katolik Roma_menganggap perilaku seksual manusia sebagai sesuatu yang suci, hampir penuh keilahian di dalam intisarinya, ketika dilakukan secara benar. Kegiatan-kegiatan hubungan seksual anal dan homogenital dianggap penuh dosa karena perilaku seksual pada dasarnya ditujukan untuk suatu kesatuan dan penerusan keturunan (meniru kehidupan Trinitas pribadi Tuhan). Gereja juga memahami kebutuhan saling melengkapi antara jenis kelamin yang berbeda untuk menjadi bagian dalam rencana Allah. Tindakan-tindakan seksual sama-jenis tidak sejalan dengan pola rancangan ini:

"Tindak-tanduk homoseksual bertentangan dengan hukum alam. Tindakantindakan ini menutup unsur pemberian kehidupan dalam perilaku seksual. Mereka tidak berasal dari sebuah tindakan saling mengisi secara seksual dan secara penuh kesih sayang yang tulus. Di dalam situasi apapun tindakan-tindakan ini tidak bisa disahkan."

Ajaran-ajaran ini tentu saja tidak terbatas pada pembahasan masalah homoseksualitas, namun juga membentuk dasar filosofi bagi pelarangan Katolik

${ }^{10}$ Az Zarkasyi, Syarhu Az Zarkasyi Juz 7, Annasyir : Darul Ibikan, h. 301. 
terhadap, contohnya, seks bebas, semua bentuk perilaku seks yang tidak alami, kontrasepsi, pornografi, hubungan seksual anal dan masturbasi. ${ }^{11}$.

Di dalam Alkitab, khususnya Perjanjian Baru, ditunjukkan bagaimana seharusnya paradigma orang Kristen terhadap LGBT (Lesbian, Gay, Biseksual, dan Transgender). Alkitab secara tegas menunjukkan bahwa homoseksualitas adalah dosa, Alkitab jelas menyebutkan bahwa homoseksualitas adalah dosa dan kekejian di mata Allah $^{12}$

Agama Hindu sebagaimana agama-agama yang lainnya di Indonesia, Hindu juga merupakan sruti atau wahyu tuhan dan juga smerti yang merupakan tafsir yang mana hindu akan merealisasi sruti dengan saat atau era dimana hindu itu dianut oleh umatnya, agama hindu bersifat universal dalam artian masih mampu mengatur sesuai dengan dijaman dulu hingga sekarang. Hindu dikenal memiliki pondamen dasar yaitu Tri Kerangka Agama Hindu: Tatwa (Filsafat), Etika (Susila/Hukum), Upacara (Ritual) tentunya akan mengacu ke kerangka agama tersebut dalam menyikapi masalah yang muncul didalam kehidupan manusia. Kehidupan manusia didalam agama Hindu tentunya harus mengacu pada setiap firman Tuhan Sang Hyang Widi Wasa/Ranying Hatalla Langit, ada ayat dalam Kitab Suci Sarasamuccaya ${ }^{165}$

Konghucu tidak mau mempersalahkan apa yang telah terjadi, tetapi khonghucu mencari solusi tentang apa yang telah terjadi dan jangan adanya sikap saling menyalahkan dengan apa yang telah terjadi. Para kaum LGBT ini perlu pembinaan yang khusus, diberi pengarahan janganlah mereka dibenci, dikucilkan maupun dihina karena mereka juga adalah manusia ciptaan Tuhan.

Dari adanya ketentuan agama-agama di atas dapatlah disimpulkan bahwa perilaku LGBT merupakan perilaku yang dilarang oleh agama-agama di indonesia, perbuatan yang dianggap tercela dan bertentangan dengan kodrat penciptaan manusia. Oleh sebab itu perilaku LGBT dianggap perilaku yang buruk dan tidak dapat

${ }^{11}$ https://id.wikipedia.org/wiki/GerejaKatolikRomadanhomoseksualitas, akses tgl 12 Januari 2017.

12 http://pmkmisiologiunpad.blogspot.co.id/2015/08/pandangan-alkitab-tentang-lgbt-lesbian. html, akses tgl 12 Januari 2017. 
dibenarkan oleh masyarakat di Indonesia yang terkenal religius, beradab dan memiliki nilai-nilai kesusilaan yang mengakar dalam dirinya ${ }^{13}$.

Setelah diuraikan bahwa LGBT merupakan tindak pidana menurut hukum yang hidup dalam masyarakat, maka pertanyaan yang ada sekarang adalah bagaimana dengan pandangan hukum pidana positif kita (KUHP)? Apakah terlarangnya perbuatan LGBT dalam hukum yang hidup dalam masyarakat dapat dijadikan dasar untuk mengkualifikasikan LGBT sebagai tindak pidana dalam hukum pidana Indonesia? Perlu pembahasan lebih komprehensif, untuk dapat sampai pada suatu kesimpulan yang dapat mempertemukan benang simpul, dari kedua konsep yang berbeda antara pengertian tindak pidana menurut hukum pidana positif dengan hukum yang hidup dalam masyarakat.

\section{Kesimpulan}

Perilaku LGBT dapat dikualifikasikan sebagai tindak pidana dengan jenis crimina extra ordinaria/mala in se, yaitu suatu perbuatan yang dianggap jahat dan merugikan oleh masyarakat meskipun tidak diatur dalam undang-undang, hal ini disebakan karena perilaku tersebut bertentangan dengan hukum yang hidup dalam masyarakat, yang sarat akan nilai-nilai adiluhung bangsa Indonesia yang religius, adil dan beradab. Selain itu perilaku tersebut juga berpotensi besar dapat menimbulkan kerugian secara tidak langsung (Indirect) bagi bangsa dan negara, berupa ancaman dekadensi moral (khususnya generasi muda), keberlangsungan eksistensi penduduk, berkembangnya kejahatan lain seperti Pedofilia dan pelecehan seksual, berkembangnya penyakit HIV AIDS dan penularan perilaku LGBT. Sehingga perilaku tersebut meskipun tidak diatur oleh Undang-undang, dapat/memungkinkan untuk dipidana, berdasarkan doktrin ajaran sifat melawan hukum materiil dengan fungsinya yang positif, sebagaimana hal tersebut telah berlaku baik dalam tataran yurisprudensi, perkembangan teori, maupun doktrin hukum pidana.

\section{${ }^{13}$ Ibid.}




\section{Saran}

Melalui akhir penulisan ini, perkenankan penulis memberikan beberapa saran dan masukan kepada beberapa pihak yang dianggap berkompeten dengan persoalan LGBT, sebagai berikut

1. Mengingat masih kuatnya pengaruh Civil Law System dalam hukum pidana dan sistem peradilan pidana di Indonesia, maka untuk lebih memantapkan pengkualifikasian LGBT sebagai tindak pidana, penting perilaku tersebut untuk dikonkretkan dalam aturan hukum tertulis (RKUHP) dengan melakukan Rekriminalisasi (menjadikan LGBT sebagai tindak pidana dengan menambah dan menyempurnakan rumusan yang selama ini telah ada dalam pasal 292 KUHP), caranya adalah dengan menghilangkan frasa 'yang diketahuinya atau sepatutnya harus diduganya belum dewasa', sehingga bunyinya menjadi 'Orang dewasa yang melakukan perbuatan cabul dengan orang lain sesama kelamin, diancam dengan pidana penjara paling lama lima tahun'.

2. Selama belum adanya aturan Undang-undang yang secara tegas melarang LGBT, aparat penegak hukum harus dapat mengisi kekosongan hukum, dengan mengakomodir hukum yang hidup dalam masyarakat sebagai sarana untuk menanggulangi persoalan LGBT. agar penyebarannya tidak terus meluas dan dampaknya akan semakin sulit untuk ditangani dikemudian hari.

3. Perilaku LGBT harus sesegera mungkin ditangani oleh pemerintah, dengan mengambil langkah-langkah kebijakan yang responsiv dan akomodatif, mengingat pembembentukan undang-undang membutuhkan waktu yang cukup lama dan proses yang panjang, maka salah satu cara yang paling mungkin dilakukan adalah dengan mengeluarkan PERPU (peraturan pemerintah pengganti undang-undang), agar persoalan LGBT tidak membuat konflik sosial yang berkepanjangan dan meluas akibat gerakan massif dari kaum LGBT yang meminta legalisasi. 


\section{DAFTAR PUSTAKA}

Abu Hasan, Al Hawi Al Kabir juz 13, dar alkutub alamiah, Bairut Libanon.

Az Zarkasyi, Syarhu Az Zarkasyi Juz 7, Annasyir : Darul Ibikan

Dar Al Kutub Ilmiyah, Bairut libanon,

html, akses tgl 12 Januari 2017.

http://pmkmisiologiunpad.blogspot.co.id/2015/08/pandangan-alkitab-tentang-lgbtlesbian.

https://id.wikipedia.org/wiki/GerejaKatolikRomadanhomoseksualitas, akses tgl 12 Januari 2017.

Ibnu Qudamah, Al Mughni juz 10, Maktabah Alqohiroh

Muhammad As-Syaukani, Fathul Qadir juz 5, Annasyir Darul Fikri

Peter Mahmud Marzuki, , 2005, Penelitian Hukum Edisi Revisi, Prenada Media Group

Taqiyud Diin Abi Bakar Bin Muhammad AlHusaini, Kifayatul akhyar juz 1, Dar AlKhair Dimisyq

Tirmidzi, Al Majalis Al Wa'idiyah Fi Syarhi Al Ahadist Khoiril Bariyah Juz 2, Annasyir

www.gayanusantara.or.id 